\title{
Idrætten og samfundsudviklingen
}

\author{
De Danske Skytte-, Gymnastik- og Idrætsforeninger \\ v/konsulent Johs. Lyngsgaard
}

Som den ældste idrætsorganisation i Danmark er vi naturligt interesseret $\mathrm{i}$ den historieskrivning og drøftelser hermed, der i dag udvikler sig.

Idrætten har udviklet sig anderledes i Danmark end i mange andre lande.

Skal vi analysere baggrunden herfor, må vi trække gamle Grundtvig frem. Ikke fordi han havde et bestemt idrætsligt sigte, men det var hans tanker om at bevidstgøre det danske folk efter den frie forfatning i 1849 - hans tanker om folkeoplysning - der var med til at tilskynde dannelsen af De danske Skytteforeninger i 1861, hvormed man bidrog til at omsætte Grundtvigs tanker om at oplyse det danske folk til aktiv handling.

Det skabte en bevægelse, hvor idrætten blev et middel til at opnå folkets bevidste fællesskab om sine historiske, praktiske, menneskelige og åndelige værdier.

Det samme syn skabte grobund for højskolerne, og det var gennem dem, vi fik det særlige danske: den folkelige gymnastik.

Skytteforeningerne havde et stærkt nationalt sigte, der fx gav sig udtryk i formuleringen: ,Vække folkeånden og værne fædrelandet“".

Kampen for den folkelige gymnastik, der blev bakket op af skytterne, idet det ofte var de samme personer, var hektisk $i$ slutningen af det forrige århundrede, hvor idrætten virkelig var engageret i den politiske udvikling.

Det skabte en udvikling, der var med til at skabe den danske historie.

I DDSG\&I er vi meget opmærksomme på den historiske udvikling, idrætten siden har haft, hvor vi nu 100 år efter må konstatere, at idrætten ikke på samme måde har indflydelse på samfundsudviklingen.

$\mathrm{Vi}$ er af den opfattelse, at idrætten i højere grad bør engagere sig $i$ samfundsudviklingen og dermed også i den historie, det vil give.

Vi hilser derfor Dansk Idrætshistorisk Forening velkommen og håber, den må få kræfter til at følge den sparsomme historie op, vi endnu har haft.

Idrætsdeltagelsen i Danmark er under stærk forvandling, hvor man konstaterer en betydelig tilvækst af bl.a. de lidt ældre. De kommer ikke med idrætslige ambitioner, men snarere med lignende forventninger, som da folk strømmede til den folkelige gymnastik for 100 år siden. Det var kroppen, man ville have dannet og plejet. 
Tilgang til idrætten har i dag også meget med en bevidsthed om nødvendig pleje af kroppen at gøre. Om vi så i dag og den kommende tid formår at sætte idrætten $\mathrm{i}$ relation til samfundsudviklingen $\mathrm{i}$ øvrigt må den kommende historie vise. 